\title{
BUREAUCRATIZING FATWĀ IN INDONESIA: The Council of Indonesian Ulama and Its Quasi- Legislative Power
}

\author{
Alfitri \\ Institut Agama Islam Negeri (IAIN) Samarinda \\ Email: al.fitri@iain-samarinda.ac.id
}

\begin{abstract}
The state has given de-jure recognition of the Council of Indonesian Ulama's (MUI) authority in establishing sharī a principles for the running of Islamic financial service in Indonesia. Given this extensive design, does MUI then expand this authority into other Islamic law fields, and if so, why and how MUI does that. This paper aims to examine MUI's policy to bureaucratize fatwā by making its Fatwa Commission the single institution, administratively and substantively, for fatwa production in Indonesia. It considers this issue in light of secondary data gathered through the documentation of Ijtima Ulama resolutions. It examines their inclusion or exclusion into the MUI's official fatwā compilation employing both normative-doctrinal and socio-legal analysis. As its formal role in the state system for the administration of Islamic legal traditions has been acknowledged, MUI continues expanding its authority by enabling its Fatwa Commission like a legislature, which will further review the Ijtima Ulama resolutions before promulgating them as a fatwa . Therefore, some of the resolutions that do not pass the review cannot/are not promulgated as a fatwā. MUI adopts this measure to increase the efficacy of its fatāwa by polishing the collective ijtihād resolutions of Ijtima Ulama which are assumed to represent all ulama in Indonesia.
\end{abstract}

Keywords: Quasi-Legislative Power, the Council of Indonesian Ulama, Collective Ijtihad, Fatwō

DOI: https://doi.org/10.20414/ujis.v24i2.412

\section{Introduction}

The role of the Council of Indonesian Ulama (Majelis Ulama Indonesia, hereinafter MUI) has been depicted as an anomaly given its vague status in Indonesian politics. Earlier in the 1980s, MUI was considered no more than the New Order authoritarian regime's creature to endorse the government policies on matters 
affecting Muslims in Indonesia through its fatāwwa (singular: fatwā) or other non-fatwa promulgation. When it recently transforms itself into an independent leader on Islamic values and becomes critical to government policies, MUI is feared to spread conservatism and impede democracy in Indonesia. ${ }^{1}$ Despite the fact, recent developments in Islamic legislation and codification in the field of shari 'a economy uncovers a pattern of institutionalizing MUI authority over Islamic law interpretation. In the case of Islamic financial services, the state now institutionalizes a mechanism for ascertaining shari 'a compliance of Islamic banks in Indonesia. The state vests MUI with authority to determine shari ' $a$ compliance, and the Shari ${ }^{-} a$ National Board, MUI's organ, run the authority technically by issuing fatāwā related to financial services. Their implementation is supervised at the financial institution level by the Shari $a$ Supervisory Board, which is appointed on the recommendation of the Sharī'a National Board. ${ }^{2}$ The Sharī'a National Board's fatāwā are then absorbed into the Central Bank Regulations using a regulatory process within the Shari $' a$ Banking Committee which is under the authority of the Central Bank. ${ }^{3}$

Why have MUI's fatāwo $\bar{a}$ been so influential in administering Islamic legal traditions within the shari 'a economy, despite not holding a monopoly on fatāwa $\bar{a}$ issuing authority in Indonesia? Previous studies on MUI have only focused on the production of fatwō in MUI and its influence on Indonesia's Muslim thoughts. For example, Hosen maintains that the government tends to defer to, or use only, MUI's opinions since MUI could be considered representative of all Islamic organizations. However, it also considered opinions from other Islamic organizations. ${ }^{4}$ Hasyim further argues that it is evident in the last ten years since other

${ }^{1}$ Syafiq Hasyim, "Fatwas and Democracy: Majelis Ulama Indonesia (MUI, Indonesian Ulema Council) and Rising Conservatism in Indonesian Islam," TRaNS: Trans-Regional and -National Studies of Southeast Asia 8, no. 1 (May 2020): 21-35.

${ }^{2}$ Elucidation of Law No. 21 of 2008 concerning Sharì 'a Banking art. 1(12), art. 26(2-3).

${ }^{3}$ Elucidation of Law No. 21 of 2008 concerning Sharì $a$ Banking, art. 26(4).

${ }^{4}$ Nadirsyah Hosen, "Behind the Scenes: Fatwas of Majelis Ulama Indonesia (1975-1998)," Journal of Islamic Studies 15, no. 2 (May 2004): 151. 
fatwā commissions of Muslim organizations belonging to Nadlatul Ulama and Muhammadiyah are not so prolific in issuing fat $\bar{a} w \bar{a}$, and they both tend to hand their authority to issue a fatwo to MUI. They issue fewer fatāw $\bar{a}$ than MUI, and they will not publish a fatwo $\bar{a}$ that has been released by the Fatwa Commission of MUI. ${ }^{5}$ Ichwan, Hosen, ${ }^{6}$ Gillespie, Nasir and Asnawi, Hasyim, and Sirry ${ }^{7}$ look at the fatāw $\bar{a}$ as a means by which MUI maintained its role in a rapidly changing political and religious environment. Gillespie and Olle ${ }^{8}$ also note MUI's increasingly conservative views on moral and social issues and its hostility toward unorthodox minority Islamic groups. Therefore, the phenomena of the expansion of MUI's influence and authority in the aftermath of the New Order regime's demise were unexplained until Lindsey published his study in 2012.

According to Lindsey, the regulatory changes since Soeharto's fall in 1998 have expanded MUI's formal role in the state system for the administration of Islamic legal traditions in Indonesia, especially in the field of shari'a economy (mu'àmalāt). ${ }^{9}$ These changes have intensified MUI's influence and the legal authority of its fatāwā. MUI thus has been granted new institutional roles by the state, even monopolies in some cases, when it comes to halal certification, Islamic finance, and the hajj pilgrimage. MUI has now begun to accrue quasi-legislative powers resembling

5 Syafiq Hasyim, "The Council of Indonesian Ulama (Majelis Ulama Indonesia, MUI) and Religious Freedom," Irasec's Discussion Papers 12 (2011): 8. Hasyim supports his conclusion from an interview with a functionary of Muhammdiyah, a member of MUI.

${ }^{6}$ Nadirsyah Hosen, "Fatwa and Politics in Indonesia," in Sharia and Politics in Modern Indonesia, ed. Arskal Salim and Azyumardi Azra (Singapore: ISEAS, 2003), 168-180.

${ }^{7}$ Mun'im Sirry, "Fatwas and Their Controversy: The Case of the Council of Indonesian Ulama (MUI)," Journal of Southeast Asian Studies 44, no. 1 (February 2013): 100-117.

${ }^{8}$ John Olle, “The Majelis Ulama Indonesia versus 'Heresy': The Resurgence of Authoritarian Islam," in State of Authority: The State in Society in Indonesia, ed. Gerry van Klinken and Joshua Barker (Ithaca: Cornell Southeast Asia Program, 2009), 95-116.

9 Tim Lindsey, "Monopolising Islam: The Indonesian Ulama Council and the State Regulation of 'the Islamic Economy,'" Bulletin of Indonesian Islamic Studies 48, no. 2 (2012): 258. 
those enjoyed by state ulama councils and state muftī elsewhere in Southeast Asia, but not previously available to any modern Indonesian fatwa $\bar{a}$-producing body. ${ }^{10}$ Lindsey admits he did not study how MUI exercised the quasi-legislative power, especially the Fatwa Commission of MUI (hereinafter the FC-MUI).

A particular analysis is made by Alfitri on how FC-MUI exercises its quasi-legislative power in the case of corporate zakat obligation in Indonesia. MUI's role in deciding to frame corporate zakat as a mandatory duty enforceable by the Indonesian government is essential because the obligation itself is ambiguous in Islamic jurisprudence. There is no concept of a legal person in classical Islam. Hence, zakat's duty only applies to natural persons, and there is no precedent for applying the duty of zakat to a legal person in classical Islam. Following confirmation of its status in the 1980s by an international zakat forum, a decision was made by the Ijtima Ulama of the All-Indonesian Fatwa Commission of MUI and Islamic organizations in 2009, requiring the payment of corporate zakat. However, the 2009 Ijtima Ulama resolution on corporate zakat has not yet been promulgated as a fatwa by FCMUI. ${ }^{11}$

This paper aims to extend previous findings by examining MUI's policy to make FC-MUI the single institution for fatwa production, administratively and substantively, in Indonesia. It argues that MUI seeks to intensify further the acceptance of its fatāwa among Muslim communities in Indonesia so that there is legal determinacy in answer to the questions posed for resolution by engaging as many fatwā commissions and Islamic organizations as possible in the fatwe production. For this purpose, MUI organizes the biannual collective ijithād forum called Ijtima Ulama, where they seek to resolve Indonesian Muslims' contemporary problems. In exercising and maintaining its status as the most authoritative institution for fatwa production, FC-MUI thus acts as the 'reviewer' of the Ijtima Ulama resolutions before promulgating

${ }^{10}$ Ibid., 259.

${ }^{11}$ Alfitri, "Whose Authority? Interpreting, Imposing, and Complying with Corporate Zakat Obligations in Indonesia" (PhD Thesis, University of Washington, 2015), 71-103. 
them fatwā. Some Ijtima Ulama resolutions that do not pass the review cannot or are not promulgated as a fatwa

The discussion in this paper begins with an overview of MUI's origin and the development of its authority. Then, it explains methods and procedures of issuing a fatwa adopted by FC-MUI. Given the extensive role of MUI in the Islamic financial service regulation, it then investigates whether MUI expand this authority into other field of Islamic law, and if so, why and how MUI does that. Finally, it examines how FC-MUI exercises its quasilegislative power through including or excluding the Ijtima Ulama resolutions into FC-MUI's official fatwā compilation.

\section{MUI's Origin and the Development of Its Authority}

MUI was officially established during the first National Conference of all Indonesian Ulama Councils on 21-27 July 1975. Its bylaws were signed by the assembly, comprising 53 leading ulama of Indonesia and a board of directors of the local MUI on 26 July 1975. ${ }^{12}$ MUI's birth results from both ulama's and the government's awareness of the need for a specific forum for ulama across Islamic organizations. ${ }^{13}$

The function of MUI initially was meant to be purely consultative. It is not allowed to become involved in practical programs such as running schools or mosques, nor practical politics. The government made these limitations per Soeharto's speech during the $1^{\text {st }}$ National Conference of ulama in 1975. Hamka, however, stated that the limitations were proposed by the ulama themselves so as not to become a rival to the government. ${ }^{14}$ Over time, however, it turns out that both government and ulama have political motives in establishing MUI. The government used

12 Majelis Ulama Indonesia, 15 Tahun Majelis Ulama Indonesia: Wadah Musyawarah para Ulama, Zu ama dan Cendekiawan Muslim (Jakarta: Sekretariat MUI, n.d.), 85-91.

${ }^{13}$ Hosen, “Behind the Scenes," 149-15015; see also Majelis Ulama Indonesia, 15 Tahun Majelis Ulama Indonesia, 46-47; Muhammad Atho Mudzhar, Fatwas of the Council of Indonesian Ulama: A Study of Islamic Legal Thought in Indonesia 1975-1988 (Jakarta: INIS, 1993), 54.

${ }^{14}$ Mudzhar, Fatwas of the Council of Indonesian Ulama, 54. 
MUI to justify its public policy related to Islam. ${ }^{15}$ On the other hand, Ulama used MUI to influence the government's public policy not to be contradictory to Islamic teachings but empathic to Muslim interests. The ulama were aware that it would be hard to ascertain Muslims' interests and be well served unless they cooperated with the regime. ${ }^{16}$

As a non-governmental organization, the birth of MUI was made possible by government approval. ${ }^{17}$ It also continues to receive funding from the state via the Ministry of Religious Affairs. ${ }^{18}$ Although the government initiated its establishment, the government does not necessarily control MUI and does not always support its law and policies affecting Muslims in Indonesia. Mudzhar found that the majority of fatāw $\bar{a}$ issued from 1975 to 1988 were neutral (eleven fatāwā) and in some cases were in opposition to government policies, e.g., the prohibition on Muslims attending Christmas celebrations. Only eight fatāwō are supportive of government policies. ${ }^{19}$ Hooker, too, found that there are fat $\bar{a} w \bar{a}$ from the 1960s and 1970s which say that it is obligatory (wājib) for Muslims to vote for Islamic political parties; this is not acceptable to the government in contemporary Indonesia. ${ }^{20}$

The shift in Indonesian politics from an authoritarian regime to a more democratic state in 1998 has also brought about changes in MUI. Ichwan argues that MUI started to play a political role using fatāwa and tausiyya (admonition). Hence, MUI's independence increased, enabling it to debate Islam's role in Indonesia actively. For example, it supported the legality of Habibie's appointment to the presidency, which was criticized as

${ }^{15}$ M. B. Hooker, "Islam and Medical Science: Evidence from Malaysian and Indonesian Fatāwā, 1960-1995," Studia Islamika 4, no. 4 (1997): 16; Hosen, "Behind the Scenes," 154.

${ }^{16}$ Hosen, "Behind the Scenes," 151.

${ }^{17}$ Hosen uses the phrase "strong suggestion", especially from the president that made the institution of a national council for ulama possible. Ibid.

18 See "Guidelines for Financial Management of MUI" in Majelis Ulama Indonesia, Compilation of Decisions: National Working Meeting of MUI in 2011, 2011 Sector Consolidation Organizations (2011), 35, 37; Lindsey, "Monopolising Islam," 261-262.

${ }^{19}$ Mudzhar, Fatwas of the Council of Indonesian Ulama, 122.

${ }^{20}$ Hooker, "Islam and Medical Science," 16. 
unconstitutional because Habibie was deemed to be a Muslim representative. It also issued three series of admonitions, which called for Muslim participation in the general election and votes for parties that fight for the aspirations and interests of the Muslim community, nation, and state, and withholding votes from nonMuslim political leaders and parties dominated by non-Muslims. ${ }^{21}$ Subsequent studies, including Nasir's and Asnawi's, ${ }^{22}$ and Gillespie's ${ }^{23}$ also found a similar pattern and argued that in the aftermath of Soeharto's New Order regime, MUI has become more independent from the state's hegemony.

The shift in Indonesian politics has also redefined MUI's position from being state-oriented to being Muslim-communityoriented. Ali Yafie characterized MUI's new orientation, MUI's General Chairman 1990 - 2000, as 'from the state to the people.'24 MUI tries to get a broader reception among Indonesian Muslims by introducing the concept of 'big tent,' a clearinghouse for all Muslim organizations in Indonesia, including the hard-line groups. ${ }^{25}$

With its new greater independence and 'inclusive' orientation, MUI is now deemed to be the most authoritative Muslim institution in Indonesia in the sphere of fatwo $\bar{a}$ production. ${ }^{26}$ According to Lindsey, the regulatory changes since Soeharto's fall in 1998 have the expanded MUI's formal role in the state system for the administration of Islamic legal traditions in Indonesia. President Yudhoyono's commitment to placing MUI in a central

\footnotetext{
${ }^{21}$ Moch. Nur Ichwan, “' Ulamā' , State and Politics: Majelis Ulama Indonesia after Suharto," Islamic Law and Society 12, no. 1 (2005): 57.

22 They specifically analyze MUI's fatwō on abortion, which differ from the State law. Mohamad Abdun Nasir and Asnawi, “The Majelis Ulama's Fatwā on Abortion in Contemporary Indonesia," The Muslim World 101, no. 1 (2011): 33-52.

${ }^{23}$ Piers Gillespie, "Current Issues in Indonesian Islam: Analysing the 2005 Council of Indonesian Ulama Fatwa No. 7 Opposing Pluralism, Liberalism and Secularism," Journal of Islamic Studies 18, no. 2 (May 2007): 202-240.

${ }^{24}$ Hasyim, "The Council of Indonesian Ulama," 6.

${ }^{25}$ Ibid., 7.

${ }^{26}$ Hosen, "Behind the Scenes," 151; Hasyim, "The Council of Indonesian Ulama," 8. Hasyim supports his conclusion from an interview with a functionary of Muhammdiyah, a member of MUI.
} 
role in matters regarding the Islamic faith has made this possible. ${ }^{27}$ Like Soeharto, Yudhoyono was keen for MUI to maintain its semiofficial, quasi-state, 'central' role as a religious 'watchdog'. By contrast to Soeharto, Yudhoyono saw MUI as a means by which ulama could influence and guide the state. He therefore actively encouraged MUI to issue fatāwa that he would consider as a policy, or even as a type of de facto law on Islamic issues that could guide state organs..$^{28}$ These changes have intensified MUI's influence and the legal authority of its fatāwā. MUI thus has been granted new institutional roles by the state, even monopolies in some cases, when it comes to halal certification, Islamic finance, and the hajj pilgrimage. MUI has now begun to accrue quasi-legislative powers resembling those enjoyed by state ulama councils and state mufti elsewhere in Southeast Asia, but not previously available to any modern Indonesian fatwā-producing body. ${ }^{29}$

\section{Methods and Procedures of Issuing a Fatwā}

Within MUI, two institutions vested to produce a fatwä: the Shari 'a National Board and the Fatwa Commission (FC-MUI). This part will focus on analyzing the FC-MUI because it is this institution that will potentially further expand the quasi-state mufti role. The FC-MUI is an organ in the MUI organization structure, vested to issue a fatwa . The leaders and members of the FC-MUI are elected periodically by its members. In its first institution in 1975, the FC-MUI comprised seven ulama representatives of Islamic organizations. This number keeps changing with every turn over of the management of the FC-MUI five-yearly. ${ }^{30}$

27 This commitment is stated several times during his speech in MUI's national meeting of 2005 and 2007. See Syafiq Hasyim, "Majelis Ulama Indonesia and Pluralism in Indonesia," Philosophy E Social Criticism 41, no. 4-5 (May 2015): 487-495; Tim Lindsey, "Monopolising Islam: The Indonesian Ulama Council and State Regulation of the 'Islamic Economy,'" Bulletin of Indonesian Economic Studies 48, no. 2 (2012): 258-259.

${ }^{28}$ Lindsey, "Monopolising Islam," 258-259.

${ }^{29}$ Ibid.

${ }^{30}$ Alfitri, “Whose Authority? Interpreting," 87. 
The FC-MUI schedules commission meetings to deliberate and issue a fatwa attended by its members, the Chief of the regional MUI, and experts on the subject matter, e.g., medical doctors, biotechnologists, and so forth, if necessary. The meeting must be held if there is a request or demand necessary to issue a fatwa from the community, government, social institutions, and MUI's response to specific problems. A fatwā can be issued in one session, or this can be after multiple sessions, depending on the complexity and the quality of the problems. Issues with much public attention are usually challenging to conclude and need to be done in several sittings, for example, fatāwwā on smoking prohibitions, Ahmadiyah, terrorism, and pluralism. Meanwhile, fatāwō on vasectomy, tubectomy, and cornea donation were issued in one session..$^{31}$

Since 2003, the FC-MUI has adopted guidance and procedure concerning fatwa promulgation. They are part of the decisions made by the $1^{\text {st }}$ Ijtima Ulama in Jakarta in 2003. Some requirements must be met for issuing a fatwo . First, it must fulfill the methodology (manhāj) because issuing a fatwa simply to meet the need (hāja), public interest (maslaha), or objectives of sharí'a (maqūsid al-sharī'a) without taking into account the religious texts (Qur'an and Hādith) whose meaning, in particular, may lead to arbitrary rulings and abuse reason. On the other hand, holding on to the religious texts rigidly without considering the public interest and objectives of shari 'a constitutes a reckless deed. ${ }^{32}$ Thus, in promulgating a fatwā, MUI refers hierarchically to Qur'an, Hādith, ijmā', qiyās, and other legal reasoning methods in Islamic legal theory, i.e., istihsān (equity in Islamic law), maslaha mursala (considerations of public interest), or sadd al-dhari'a (blocking the means). ${ }^{33}$

There are three approaches employed by the FC-MUI: 1) Nas qat'iy approach, 2) Qawliy approach, 3) Manhājiy approach. The Nas qat 'iy is done by referring to the text of Qur'an and Hādith if

${ }^{31}$ Ibid., 88.

32 Ibid.; Majelis Ulama Indonesia, Himpunan Fatwa MUI Sejak 1975 (Jakarta: Erlangga, 2011).

33 "Pedoman dan Prosedur Penetapan Fatwa Majelis Ulama Indonesia, chapter II 'Basic and Character of Fatwa', Chapter III 'Methods to Promulgate Fatwa,'” n.d. 
both present the answer for the questions raised. If the answer is not available, then the jurists employ the Qawliy approach first and, if not sufficient, then the Manhäjiy approach. The Qawliy approach is done by referring to classical jurists' opinions documented in classical Islamic jurisprudence books. If there are conflicting opinions from classical jurists, the FC-MUI will first try to reconcile the opinions (al-jam ' $u$ wa al-tawfiq). If this step fails, the FC-MUI will choose the most reasoned opinion using the comparative method in Islamic legal theory (figh al-muqārana). If the opinion is not relevant anymore because of its impracticality or the adequate cause ('illa) of a ruling has changed, the opinion will be reviewed. When there is no single opinion on the subject matter raised in the book of figh, the FC-MUI then apply the Manhajiy approach, the process of promulgating fatwa employing canons of interpretation (al-qawā'id al-ușuliyya) and proofs of sharì'a (dālil shar ${ }^{(\bar{\imath})}$ developed by classical jurists including qiyās, maslaha mursala, and sadd al-dharī'a. ${ }^{34}$ In practice, however, the methods above are not followed consistently as proved by Hosen and Mudzhar. ${ }^{35}$

FC-MUI (and all fatāwō issuance bodies in Indonesia) implements collective ijitihād instead of individual ijitihād. The lack of epistemic authority correlates with the practice of collective ijtihad because of individual expertise, e.g., Qur'an exegesis, Hādith, Islamic legal theory (ușul al-figh), or Islamic jurisprudence (figh) can support each other's arguments during fatwā deliberation. The collective ijtihad practice even makes possible other than Islamic science experts. Their involvement is now considered instrumental in order to yield a fatwo $\bar{a}$ that is relevant to contemporary life. ${ }^{36}$ Some contemporary Islamic jurists support the practice considering the qualification of contemporary ulama to perform ijtihād and the crisis of thought in the Muslim world,

${ }^{34}$ Ibid.

35 See Hosen, "Behind the Scenes," 149; Mudzhar, Fatwas of the Council of Indonesian Ulama, 119.

${ }^{36}$ Nadirsyah Hosen, "Nahdlatul Ulama and Collective Ijtihad," New Zealand Journal of Asian Studies 6, no. 1 (2004): 5-6. 
e.g., Majmā' al-Buhūth al-Islāmiyya, a forum of leading ulama of Islamic countries in its first conference in $1964 .{ }^{37}$

\section{Ijtima Ulama Resolution and Its Inclusion/Exclusion to the MUI's Fatwā}

Since 2003, MUI has organized an inclusive collective ijtihād forum through an Ijtima Ulama of all FC-MUI and all 'Ormas' Islam (Islamic social organizations especially those which have fatwo $\bar{a}$ institutions in their organizational structure. Of around 26 decisions of three Ijtima Ulama (those held in 2003, 2006, 2009) ) $^{38}$ only five decisions have been promulgated as fatāww $\bar{a}$ of FC-MUI. They concern (1) bank interest; (2) the determination of the first day of Ramadān, Shawwāl, and Dhulhijja, (3) terrorism; (4) Short Message Service (SMS) prizes; and (5) unregistered marriage. Of these five fatāwā, four fatāw $\bar{a}$ were promulgated only with one general meeting of FC-MUI while the fatwa concerning bank interest was promulgated after three sessions. Most fatāwa promulgated from the decisions confirm the rulings adopted by the Ijtima Ulama but with different redactions. The rest of the decisions of the Ijtima Ulama have not been promulgated as fatāwa for following reasons: first, they need further study by FC-MUI (e.g., in the case of corporate zakat); second, FC-MUI has issued fatwa earlier with the similar subject matter, or it issued a fatwo afterward without referring to the decision although, it has similar subject matter; and third, they are more like non-fatwa documents because of lacks of normative points. Detailed analysis on how FCMUI has treated the decisions of the Ijtima Ulama up till the publication of MUI's fatwā compilation in $2011^{39}$ are presented below:

The $1^{\text {st }}$ Ijtima Ulama, Jakarta, 2003

The first resolution is about Bank Interest. It rules that it is ribā, thus prohibited (harām) especially for Muslims who live in an area

${ }^{37}$ As quoted by Hosen, Ibid., 6.

38 This excludes recent decisions because the first compilation of fatwo of MUI and FC-MUI was published in 2011.

${ }^{39}$ This is when the compilation of fatwa from 1975 published in 2011 by the secretariat of MUI, see Majelis Ulama Indonesia, Himpunan Fatwa MUI Sejak 1975. 
where the branch of Islamic banks is available. Muslims can do business with conventional banks based on necessity/need (darurah/hajah) if the Islamic bank is not available. This resolution was promulgated as the MUI's fatwō No. 1 the Year 2004 concerning Bank Interest (Bunga), which has the same ruling as the resolution. FC-MUI met to discuss further this 2003 decision on January 3, 2004, January 17, 2004, and January 24, 2004. The promulgation of the fatwe was signed on January 24, 2004.

The second resolution concerns the Determination of the First day of Ramadan, Shawwal, and Dhulhijjah. The forum decided that: 1) the determination is done using moonsighting (ru'yah) and astronomical calculation (hisab); 2) all Muslims in Indonesia are obliged to abide by the decision of government with regards to the determination; 3) to determine the first day of Ramadan, Shawwal, and Dhulhijjah, the Minister of Religious Affairs is obliged to consult MUI, Islamic social organizations and concern institutions. The Ijtima Ulama decision was then promulgated as the MUI's fatwo $\bar{a}$ No. 2 the Year 2004 concerning the determination of the first day of Ramadan, Shawal, and Dhulhijjah. The same rulings as the 2003 decision. However, the fatwa adds "... by the government qua the Minister of Religious Affairs and the determination is effective nationally"; and point 4) "the result of moonsighting from the area outside Indonesian territory but with the same matla' (the position of the rising and setting sun) can be used by the Minister as a reference." FC-MUI met on January 24, 2004, and signed the promulgation of a fatwa on the date. ${ }^{40}$

The final resolution is about terrorism. The forum decided that: 1) committing an act of terror, either perpetrated by an individual, group, or state, is prohibited (haram); 2) performing jihad is obligatory (wajib). The resolution was promulgated as the MUI's fatwā No. 3 the Year 2004 concerning Terrorism, which has the same rulings as the resolution. FC-MUI met on January 24,

40 In 1980, FC-MUI issued a fatwā on this matter. The rulings were: 1) regarding the determination of first Ramadan and Shawal, Muslims should follow the majority opinion in figh, i.e., using matla` as the point of reference; 2) unlike the determination of the first day of Ramadan and Shawal, the first day of Dhulhijjah is determined based on matla of each country; hence, Indonesia cannot follow other countries in determining the Eid al-Adha festival day. 
2004, and signed the promulgation of a fatwo on the date. The Board of Directors of MUI also signed the fatwa. MUI wanted to clarify that the concept of jihad is not the same as terrorism, just like what other Islamic organizations, e.g., the Organization of Islamic Conference, did.

\section{The $2^{\text {nd }}$ Ijtima Ulama, Ponorogo, East Java, 2006}

The forum was divided into two commissions. Commission A discussed Issues of Nationalism. They deliberated four subject matters, and none of the Commission A resolutions have been promulgated as an MUI's fatwō. The first subject matter was strengthening the form and existence of the Unitary State of the Republic of Indonesia. It is common practice in MUI to respond to Indonesia's current socio-political situation by issuing a fatwā or admonition. The background of this decision was separatist movements in the Moluccas and Papua. The commission decided: 1) Since the territory of the unitary state of Indonesian republic (NKRI) is populated mostly by Muslims, Muslims are obliged to maintain the integrity of NKRI, including from any form of treasons and separatist movements; 2) the state is obliged to take any necessary measures to prevent treason and separatist movements such as creating justice, security, prosperity, and raising awareness to the perpetrators; 3 ) any form of treason and separatist movements fall under the category of bughat (treason) crime, and bughat is prohibited and must be eradicated by the state.

The second subject matter was the Harmonization of a religious frame of thoughts in a nationalism context. The commission declared: 1) values brought by modernization and globalization which accord to Islamic doctrines and bring virtues may be accepted as universal Islamic values; 2) Conversely, those against Islamic doctrines and that bring corruption to society (mafsadat) must be rejected; 3 ) in the national life, religion should be utilized as a source of inspiration and guidance; hence, there should not be conflicts between religious frames of thoughts and nationalism frames of thought.

The third subject matter was equating mindset in religious issues. The commission declared: 1) difference of opinion is 
recognized in Islam, but it should not be understood as freedom with no boundary; 2) difference of opinion can be tolerated as long as it is still within majal al-ikhtilaf (matters susceptible to the difference in Islam); beyond that is categorized as heretical; 3) in dealing with majal al-ikhtilaf, Muslims should find the meeting point at maximum efforts.

Both resolutions sound more like an admonition or recommendation than a fatwa because of the lack of normative points. Hence, it can be understood why they are not promulgated as a fatwō.

The fourth subject matter was coordinating strategic steps in dealing with religious issues. The commission decided: 1) Muslims need to streamline their movements; 2) effective movements are characterized as rehabilitative, coordinated, synergized, mutually supportive, and productive; 3 ) to achieve that, MUI is expected to coordinate, synchronize and synergize Muslim movements. As it also lacks normative points, this decision thus falls into the category of admonition or recommendation. There is a point in the decision where MUI positions itself as the coordinator of Islamic organizations in Indonesia. Process tracing of MUI's role in Indonesia reveals that it has actively performed a role as an initiator and coordinator of socio-economic, socio-cultural, and socio-political programs for Muslims. ${ }^{41}$

Another commission of this Ijtima Ulama discussed issues of contemporary events. There are eight subject matters sought for answers. The first one is about Short Message Service (SMS) Prizes. The commission decided: 1) SMS Prizes are prohibited (haram) because they contain elements of gambling (maysir), wasting money (tabdzir), deceitful (gharar), harmful (dlarar), ighra', ishraf (redundant). There is an exception to SMS prizes which provide prizes, not from the participants. 2) Prohibited SMS Prizes can be in the form of a contest, quiz, sport, games, and competition, which promise prizes drawn among SMS senders. 3) Prizes of prohibited SMS are those coming from premium charges of SMS sent by participants in which the charges way beyond the regular

${ }^{41}$ Tim Lindsey, Islam, Law and the State in Southeast Asia, vol. 1: Indonesia (London: I.B. Tauris, 2012), 117-154. 
rate of a text message; 4) the prohibited status of SMS prizes generally applies to event organizers, telecommunication providers, participants, and other sponsors.

This resolution was then promulgated as the MUI's fatwā No. 9 the Year 2008 concerning Short Message Service Prizes. The same rulings as the 2006 decision with different redaction: point 3 is included in point 1; point 2 is taken out and changed to "SMS Prizes which do not contain elements mentioned in point 1 are considered neutral/permissible (mubah). In reviewing the resolution, no further meeting was held by FC-MUI; the promulgation of the fatwa was signed on September 17, 2008. The fatwa also considers research findings by the Advisory and Supervisory Task Force for Free Lottery set up by the Indonesian Telecommunication Regulation Agency (BRTI). The research finds that SMS Prizes have made significant losses on society's side because they encourage people to send SMS as frequently as possible. Simultaneously, participants cannot detect the mechanism to draw winners and the number of prizes. Hence, the BRTI has instructed telecommunication providers to stop the SMS Prizes features in their services.

The second subject matter was about unregistered marriage (nikah bawah tangan). The commission decided: 1) the participants of Ijtima Ulama agree that the government office must register a marriage in order to prevent adverse impacts that may arise from non-registration (sad adh-dharia); 2) yet, unregistered marriage (nikah bawah tangan) is valid according to Islamic law (figh) because it fulfills the requirements of marriage in Islam; if there are harmful effects from such marriage, then it is prohibited (haram). This resolution was then promulgated as the MUI's fatwa No. 10 the Year 2008 concerning unregistered marriage; it has the same rulings with different redaction. In reviewing the resolution, no further meeting was held by FC-MUI, the promulgation of the fatwa was signed on September 17, 2008. The fatwa responds to a proposal to criminalize perpetrators invoked by the substantive marriage law's draft bill for the religious courts. ${ }^{42}$

${ }^{42}$ See Alfitri, "Whose Authority? Contesting and Negotiating the Idea of a Legitimate Interpretation of Islamic Law in Indonesia," Asian Journal of 
The third subject matter was about financing national development with foreign loans. The commission decided that It is permissible if the internal funding sources are insufficient, and with conditions: a. the foreign loan is utilized to achieve a selffinancing state later and to sustain the national development; $b$. the foreign loan is utilized effectively and efficiently for the interest of people at large. Hence, it is prohibited to embezzle it; c. the foreign loan is acquired through the financial scheme free from interest; $d$. if not possible, the conventional financial scheme is allowed on the ground of necessity (dlarurat); e. the foreign loan does not contain inequitable terms and conditions; $f$. the government must seek alternative sources beyond debt such as direct investment, issuing sharia bond, voluntary sector funds (zakat, waqf, and grant), and other sources which not contradict with Sharia.

Despite the supportive rulings of government policy resolution on foreign loans, this resolution is not promulgated as an MUI's fatwā. The same situation also applies to the fourth subject matter concerning the management of natural resources. The forum decided: 1) natural resources, especially those that affect the lives of people at large [the decision mentioned the categories of natural resources cited in classical figh: water, fire, grassland, forest, and minerals] must be managed by the state, and their benefits must be returned to the people in the form of essential need services; 3) sustainable development must be adopted in exploring and exploiting natural resources; 4) the use of environmental-friendly technology to achieve Eco-efficiency 5) law enforcement is necessary to avoid environmental damage and pollution. It sounds more like an admonition or recommendation than a fatwa $\bar{a}$ because it lacks a normative point. Despite the fact, MUI established a new institute under its aegis concerning the improvement of natural resources.

The fifth subject matter was about transferring the embryo to a surrogate womb. The commission decided: 1) It is prohibited

Comparative Law 10, no. 2 (December 2015): 197; see also Alfitri, "Protecting Women from Domestic Violence: Islam, Family Law, and the State in Indonesia," Studia Islamika 27, no. 2 (2020): 303-304. 
(haram) if the transfer happens from an embryo generated from a husband's sperm and his wife's ovum to a surrogate womb; 2) idem, if it happens from an embryo generated from a husband's sperm and his wife' ovum to his other wife's surrogate womb; 3 ) idem point 1 if the reason is the husband and wife do not want the pregnancy; 4) the legal status of a child born from point 1-3 situation is "child born outside wedlock." Thus, the child only has a legal relationship with his/her mother. Despite its normative points, this resolution has not been promulgated as an MUI's fatwā.

The sixth subject matter was about alternative medicine. The forum decided that alternative medicines are medical treatment sought from other medical practitioners (doctors or nurses). It is prohibited if alternative medicine practices contain syirik (association of God with others) and sihir (black magic). If free from both elements, it is permissible. Medical treatment with prohibited things is unlawful. This resolution has not been promulgated as an MUI's fatwā. However, the central MUI will institute a task force further to study the criteria of syirik in medical treatment.

The seventh subject matter was about critical problems in auditing halal products. The commission decided as follows: 1) stunning the animals before slaughtering them is permissible (mubah) on the grounds of easing the process, especially on a big scale farm; yet, MUI recommends the use of this method as a last resort; 2) the use of human flesh for drugs and cosmetics is prohibited (haram); likewise, the use of human hair for food products; 3) the use of microbes originating from a baby's stool, after several times of culturing process, is permissible for food processing; 4) the use of alcohol and ethanol is referred to under an existing MUI's fatwā.

These four normative points received different responses from FC-MUI. Point (1) is not promulgated as an MUI's fatwa a and neither point (2). Nevertheless, the subject matter of point (2) was already promulgated as a fatwa through the MUI National Meeting VI (Munas) No. 2/Munas VI/ MUI/2000 concerning the use of human flesh, placenta, and human urines for drugs and cosmetics making; the same rulings. Point (3) is not promulgated as an 
MUI's fatwā, but FC-MUI issued a fatwā No 1 the Year 2010 concerning the Use of Microbe and Microbial Products in Food Products. As for point (4), there have been already several fatawa on the subject matter. For example, the MUI's fatwa a concerning alcohol's legal status in beverages promulgated on October 1, 1993, but it is not numbered. Likewise, the MUI's Fatwā No 11 the Year 2009 concerning the legal status of Alcohol. Hence, this resolution is redundant.

Last but not least is the subject matter concerning issues on legislation. The forum recommended on drafting bills, e.g., in the bill of zakat law amendment: 1) change title from zakat administration law to zakat law; 2) BAZNAS as the coordinator of existing zakat agencies; 3) sanction for infringement not only imposed on zakat agencies and zakat evaders, but also upon the beneficiaries; 4) zakat should also become a tax credit; 5) amendment to zakat law should be followed. Since this is a recommendation, it was not meant to be promulgated as an MUI's fatwa $\bar{a}$. MUI always issues recommendations concerning zakat (administration) law in each of its national events: national meeting, national workshop, and ijtima ulama; either before the issuance of regulations related to the institution zakat agencies (BAZIS), zakat law No. 38/1999 and after their issuance. The recommendations revolve around the issue: channeling zakat payments to zakat agencies instead of direct payments to beneficiaries; the state acting as the zakat collector; the obligation of zakat should be enforced with sanctions for the evaders; tax treatment for zakat payers. ${ }^{43}$

\section{The $3^{\text {rd }}$ Ijtima Ulama, Padang Panjang, West Sumatera, 2009}

There are two significant issues deliberated during the $3^{\text {rd }}$ Ijtima Ulama, namely, nationalism and contemporary figh issues. The latter then was divided into two commissions (B-1 and B-2).

${ }^{43}$ See Alfitri, "Whose Authority? Interpreting," 115-118; for the timeline of zakat imposition's controversy and the MUI's fatwa that follow it, see Alfitri, "Religion and Constitutional Practices in Indonesia: How Far Should the State Intervene in the Administration of Islam?," Asian Journal of Comparative Law 13, no. 2 (December 2018): 401-406. 
In the nationalism issues, the commission discussed four subject matters: 1) inter-religious of the relationship among people; 2) role of religion in developing moral character; 3 ) implementation of Islam as a mercy for the universe; 4) voting rights in the general election. None of the recommendations are promulgated as an MUI's fatwa because they are more like admonitions than fatwā. On subject matter four, the commission stipulated: 1) it is an obligation to elect a leader whose character is as follows: a man of faith, honest, trustworthy, active and attentive, capable and fighting for the interests of the Islamic community, and 2) to elect a leader who does not have the characters above or not give one's vote at all while there is the candidate with the above characteristics is prohibited (haram). Similar to every other election post after the fall of the authoritarian New Order Regime, MUI always issues an admonition encouraging Muslims to vote for candidates who will care about Muslims' interests in Indonesia. ${ }^{44}$

Commission B-1 deliberated the issues of contemporary fiqh on: 1) problems related to waqf (Islamic trust); 2) problems related to zakat ('amil, expenses incurred from zakat management, and corporate zakat); and 3) legal status of smoking. None of the three resolutions made are promulgated as the MUI's fatwā. On the waqf matter, the commission decided: 1) changing the object of waqf is permissible on the ground to realize public benefits; 2) changing cash waqf (wakaf uang) to commodity waqf, and vice versa, is permissible because of public benefit and necessity; 3 ) the object of waqf can be sold on the ground of need, and the proceeds of such sale must be used to buy other commodities as substitute waqf; 4) the implementation of point 1-4 can only be done after the permit of Minister of Religious Affairs and MUI's advice; 5) trustees must understand their duty and responsibility, including the understanding of investment. By examining the existing MUI's fatwa $\bar{a}$, it was found that a fatwo (without numbering) concerning the permissibility of cash waqf was issued earlier by FC-MUI on May 11, 2002.

${ }^{44}$ See Ichwan, " 'Ulamā' , State and Politics." 
On zakat matters, the commission decided: 1) 'amil (individual or zakat agency appointed by or authorized by the government) is entitled to maximally $12.5 \%$ of zakat proceeds given its status as one of eight beneficiaries; 2) 'amil is not allowed to ask for commission beyond its right above, and to receive any gift from zakat payers; 3) 'amil is not allowed to give any gift bought or made with zakat proceeds to zakat payers; 4) 'amil is not allowed to receive any gift from zakat payers about its duty as zakat collectors; 5) direct or indirect expenses incurred from zakat distribution must be paid with the amil share of the zakat proceeds; if insufficient, it can be paid from other charity funds beyond zakat proceeds; 6) corporations/companies, which fulfill terms and conditions of zakat payers, are obliged to pay zakat in their capacity as legal entities (shakhsiyah itibariyah) and representative (wakil) of the shareholders.

Regarding this resolution, as far as the problems related to 'amil' are concerned, FC-MUI then issued a fatwā No. 8 the Year 2011 concerning `Amil Zakat (Zakat Agency). The fatwā does not make any reference to the decision of 2009 Ijtima Ulama concerning zakat problems. However, the rulings are the same as the 2009 decision with different redaction. They are: operational costs of an 'amil are provided by the government; in case of absence or lack of government funding, the operational costs may be taken from 'amil's share of zakat proceeds [yet, the fatwa does not mention $12.5 \%$ share]; 'amil who receive a salary from the government or private NPO are not entitled to their share of zakat proceeds. FCMUI has not promulgated it as the MUI's fatwo given its controversial subject matter and further studies required for corporate zakat obligation resolution. ${ }^{45}$

On the legal status of smoking, the commission decided: 1) the participants agree that there is a difference of opinion regarding the legal status of smoking: between disapproved (makruh) and prohibited (haram); 2) the participant agree that smoking prohibited if it is done in public spaces, by children, and by pregnant women.

${ }^{45}$ Alfitri, “Whose Authority? Interpreting," 95-102. 
Commission B-1 deliberated on vasectomy, Yoga, eye bank, other human flesh donors, minor marriage, and consuming halal food. On vasectomy, the commission decided that it was prohibited because the recanalization cannot guarantee that the person's fertility will return to normal. It is not promulgated as an MUI's fatwō because FC MUI issued a fatwā on the prohibition of vasectomy and tubectomy back in 1979. However, this decision further confirms the previous fatwo on vasectomy. The background of the decision was new developments in vasectomy recanalization.

On Yoga, the commission decided: 1) The practice of Yoga, which is a pure manifestation of other religious ritual and spiritual is prohibited for Muslims; 2) the proof of Sharia for that is sadd adh dhariah (blocking means, in this regard, from syirik or association of God with others); 3) Practice of Yoga which is a form of respiratory exercise is permissible (mubah). It is also not promulgated as an MUI's fatwā. This decision's background is a fatwa on Yoga's prohibition issued by Kelantan, Malaysia's fatwā committee.

On eye bank and other human flesh donors, the commission decided: 1) cornea transplantation is permissible on the ground of necessity; 2) organ transplantation is permissible based on his/her will; 3) donating one's cornea or organs during his/her life is prohibited; 4) point 2 is done voluntarily not commercially; 5) Eye Bank is permissible if the process (taking it from the donor and transplanting it to the beneficiary) accord with Sharia. Like vasectomy resolution, the eye bank and another human flesh donor are not promulgated as an MUI's fatwo $\bar{a}$. FC-MUI has issued a fatwa on the permissibility to donate one's cornea based on his/her will.

On minor marriage, the commission decided: 1) Islam does not give a minimum age of marriage definitively; eligibility of marriage is marked by the age where one is capable of acting and of receiving rights; 2) minor marriage thus is valid as long as it fulfills the marriage terms and conditions, but it is prohibited if it inflicts harm upon the minor; 3 ) to realize the benefit of marriage; the minimum age of marriage is based on the standardized age outlined by the Marriage Law (19 years for men and 16 years for 
women). This decision's background was the marriage of a 12year-old girl with a businessman in central Java, which put Islamic marriage jurisprudence become the public spotlight (again). FCMUI, however, has not promulgated it as an MUI's fatwo

Last but not the least, the commission decided on consuming halal food as follows: 1) Halal food security is Muslims' right; 2) food products, medicines, and cosmetics that cannot be verified as halal must be avoided until their status clear; 3) to guarantee that consumer products used by Muslims are halal, producers are called to certify their products immediately; 4) halal certification must be carried out by the authoritative institute, viz. LP POM MUI; producers who gained the halal certificate have to maintain the halal status by implementing the Halal Warranty System of LP POM MUI; 5) the government must supervise the halal status of consumer products. Even though it is not promulgated as an MUI's fatwā, FC-MUI has issued several fatāw $w \bar{a}$ related to food and its processing and whether this complies with sharia, as well as chemical ingredients used in food, medicines, and cosmetics. Thus, this resolution is more concerned with making the LP-POM MUI the authority in halal food auditing and certification.

\section{Quasi Legislature and the Return of Epistemic Authority in the Administration of Islamic Legal Tradition}

As mentioned, from 26 decisions of three Ijtima Ulama (2003, 2006 , 2009) only five decisions have been promulgated as fatāwo $\bar{a}$ of FC-MUI. The rest have not been declared officially by the FC-MUI as MUI fatāw $\bar{a}$ based on the publication of the 2011 MUI's fatwa compilation book. ${ }^{46}$ Since 2003, MUI has organized an inclusive collective ijtihād forum through an Ijtima Ulama of all FC-MUI and all 'Ormas' Islam (Islamic social organizations especially those which have fatwo institutions in their organizational structure)

${ }^{46}$ In 2015, the latest edition of the MUI's fatwa compilation book was published. It is likely that the resolutions of the Ijtima Ulama were (or were not) then declared officially as MUI's fatwa $\bar{a}$. Nevertheless, this fact does not negate the fact that FC-MUI has acted as a quasi-legislature because the resolutions were redeliberated by FC-MUI and promulgated in accordance with the official format of the MUI's fatwā. 
where they seek to resolve contemporary problems faced by Indonesian Muslims.

Even so, the resolution produced by the Ijtima Ulama forum is not an MUI's fatwa because as an organization, it is FC-MUI that is given the authority to promulgate the fatwo in MUI. Administratively, FC-MUI is mandated to promulgate MUI fatāwa following a standard format that resembles the format of statutory regulations. For fatāw $\bar{a}$ related to the Sharia economy, the mandate is given to the MUI National Sharia Council. Unlike previous publications, current publications include not only fatwo's number, year, date of assent, and signature of FC-MUI's chairman and secretary but also the background of the fatwo $\bar{a}$, explanation, and elucidation of each proof of shari 'a used. Other institutions under the MUI only issue non-fatwā documents such as tausiyah (general opinions or recommendations), tadzkirah (admonitions), amanat, (instructions), pernyataan sikap (position statements), himbauan (appeals), and sumbangan pemikiran (contributions to thought)). ${ }^{47}$ Concerning Ijtima Ulama, FC-MUI assists MUI in preparing for these activities in the form of holding a national coordination meeting for MUI leaders (daily chairperson, all FC-MUI administrators, and MUI institutions related to topics to be discussed in the Ijtima Ulama forum) with regional MUI administrators (regional FC-MUI and LPPOM-MUI administrators). The agenda for this meeting is usually the preparation of an initial draft of Ijtima Ulama and gathering aspirations on other issues that need to be discussed at the Ijtima Ulama forum. Before Ijtima Ulama is held, FC-MUI will distribute

47 Lindsey, Islam, 1: Indonesia:138. One of the MUI institutions that frequently issues non-fatwa documents is the Ukhuwah Islamiyah Forum. After Suharto's resignation as president in 1998, hardline Islamic groups, such as MMI, HTI, FPI, have become part of the Ukhuwah Islamiyah Forum. Ibid., 1: Indonesia:123, 138, 408-409. This factor is what makes non-fatwa documents such as MUI's tausiya have a large impact on the national politics because they have loyal followers who will carry it out even though it is not a fatwā. Ichwan, "'Ulamā', State and Politics," 45-49; Gillespie, "Current Issues in Indonesian Islam," 213. 
all of this paperwork to the participants according to the appointment of their respective discussion commissions. ${ }^{48}$

Substantively, FC-MUI controls the quality and consistency of MUI fatāwa according to the MUI's fatwā methodology (manhāj). MUI has been heavily criticized for problems with the consistency of fatāw $w \bar{a}$ and poor fatāwā documentation. Also, there is a problem with the communication of fatāwa to users because there is no mention of the legal basis and considerations for issuing a fatwe, only rulings. ${ }^{49}$ Regarding the Ijtima Ulama forum, FC-MUI sees the ineffective process of discussing recommendations that will become an MUI's fatwā, because: first, not all participants came to the forum well prepared even though FC-MUI has sent out the working papers in advance; second, arguments were mainly proposed based on logic, not on the religious texts or books of figh; third, the discussion was intense but vocal speakers in the forum were not necessarily those with the strongest opinions. ${ }^{50}$ In fact, MUI held a Ulama Ijtima because it seeks to further intensify the acceptance of its fatāw $\bar{a}$ among Muslim communities in Indonesia so that there is a legal determinacy in the answer to the questions posed for resolution. Because the quality of the resolution produced by Ijtima Ulama has not yet reached the manhāj fatwā issuance adopted by MUI, FC-MUI thus acts as the 'reviewer' of the Ijtima Ulama resolutions prior to promulgating them as a fatwā. Some Ijtima Ulama resolutions which do not pass the review, therefore, cannot or are not promulgated as a fatwa $\bar{a}$. This measure is adopted by MUI because there is no official mufti office in Indonesia, while the government (and also some community/community organizations) need a view of the Islamic law that can be considered to represent Islam in Indonesia. Because of this vacuum and because of de-facto ${ }^{51}$ and de-jure ${ }^{52}$

48 See "Jelang Ijtima Ulama 2012, Digelar Rakor Fatwa MUI se-Indonesia," available from www.mui.or.id/index.php?view=article\&catid=1\%3Aberitasingkat\&id=601\%3Ajelang-ijtima-ulama-2012, accessed 30 November 2020; see also Alfitri, "Whose Authority? Interpreting," 101-102.

${ }^{49}$ Ibid., 87-93.

${ }^{50}$ Ibid., 101.

${ }^{51}$ Although the Shari' a National Board was instituted in 1999 but it was only recognized in 2008 by the Law No. 21 of 2008 concerning Shari 'a Banking, Nafis 
recognitions on the authority of MUI in the state administration of Islamic legal tradition in the field of sharia economy, halal certification, hajj management, and public health matters, FC-MUI expands the scope of its authority in all fields of Islamic law by preparing, organizing, reviewing, and promulgating Ijtima Ulama resolutions. ${ }^{53}$

Following its polity as a non-secular and non-Islamic state, Indonesia does not have an official mufti institution where the government consults and asks for Islamic legal opinions representing Muslims in Indonesia. In fact, the interpretation of shari ' $a$ is considered to be the role of jurists. Islamic jurists gained the authority of lawmaking in Islam because the so-called epistemic authority attributed to them. Epistemic authority is the authority acquired through knowing the law and how it was to be derived, interpreted, and applied from its source: God's words. ${ }^{54}$ In the history of Islamic jurisprudence, the development of doctrine and method of Islamic law carried out by Islamic jurists led to Islamic schools of law (madhhab). There were hundreds of madhhab which finally crystalized into four schools of Islamic law

found that 63 fatāwa out of 65 fatāwa of the Board (96.92\%) from 2000 to 2007 had been absorbed into the regulations of Central Bank and Ministry of Finance. M. Cholil Nafis, Teori Hukum Ekonomi Syariah: Kajian Komprehensif tentang Teori Hukum Ekonomi Islam, Penerapannya dalam Fatwa Dewan Syariah Nasional dan Penerapannya ke dalam Peraturan Perundang-undangan (Jakarta: Universitas Indonesia, 2011), 137.

${ }^{52}$ MUI has become member of the Ministry of Health's Advisory Board for Health and Shari' $a$ since the 1990s. The Board consists of representatives of the Ministry of Health, medical experts, and ulama (mostly are from MUI) and is responsible for advising the Ministry in matters where medical and religious concerns could collide. After the promulgation of Law No 23 of 1992 concerning Health, the Board was transformed into the National Health Advisory Body as per the Presidential Decree No. 12 of 1994. Wahiduddin Adams, Pola Penyerapan Fatwa Majelis Ulama Indonesia (MUI) dalam Peraturan Perundang-Undangan 19751997 (Jakarta: Bagian Proyek Peningkatan Informasi Penelitian dan Diklat Keagamaan, 2004), 174, 180-181.

${ }^{53}$ Lindsey, Islam, 1: Indonesia:154.

${ }^{54}$ Wael B. Hallaq, “Juristic Authority vs. State Power: The Legal Crises of Modern Islam," Journal of Law and Religion 19, no. 2 (2003): 245; see also Wael B. Hallaq, Authority, Continuity and Change in Islamic Law (Cambridge: Cambridge University Press, 2001), 1-23. 
in Sunni Islam: Hanafiyya, Malikiyya, Shafi iyya, and Hanābila. After these four Islamic schools were established circa the 10th century, some consensus formed that authority to interpret Islamic law was held by jurists associated with one of the four madhhab. To be a member of one of these existing guilds, a jurist must undergo training in the madhhab's specified figh literature under a recognized scholar's supervision. One must undertake training in the method of interpretation adopted by the madhhab and study the standard figh texts listed by the madhhab. Once a candidate has completed the training and is accepted into the guild, his achievement would be recognized in the form of a license (ijazza) to transmit and further elaborate upon legal rulings consistent with the established doctrines of the madhhab. ${ }^{55}$

In the modern period, Islamic jurisprudence management's established mechanism has broken down across the Muslim world. Due to Muslim countries' western colonialization and the replacement of shari 'a with western codes, less comprehensively in family law. Classically trained jurists are no longer considered the only authoritative interpreters of shari $a$ and their madhhab's doctrines. The appropriateness of traditional methods is also questioned in the modern world. Thus, the agreement outlined above about the authority of jurists collapses. ${ }^{56}$ When Muslim countries gain their independence and want to Islamize their laws, instead of promulgating the figh as the law of the land, the state gives the authority to its organs (legislature, Supreme Court, or Ministry of Religious Affairs), which often do not apply Islamic legal theories when drafting the law. ${ }^{57}$

This authority conflict is partly solved with siyassa shar iyya, where ulama and the government create and share Islamic law vision. ${ }^{58}$ Some Muslim countries institutionalize siyāsa shar 'iyya: the Grand mufti in Egypt, for example, is called Dār al-Iftā; it is a government agency established in 1895. On important issues,

55 Clark B. Lombardi and R. Michael Feener, "Why Study Islamic Legal Professionals?," Pacific Rim Law \& Policy Journal 21, no. 1 (January 2012): 5-6.

${ }^{56}$ Wael B. Hallaq, A History of Islamic Legal Theories: An Introduction to Sunni Usul al-Figh (Cambridge: Cambridge University Press, 1997), 209-254.

${ }^{57}$ Alfitri, "Whose Authority? Contesting," 191-212.

${ }^{58}$ Lombardi and Feener, "Why Study Islamic Legal Professionals?," 9. 
issuing an official fatwā is taken care of by the Muftī Sheik, while more routine fatāwa are handled by dozens of subordinate muftis, via phone and internet. In Saudi Arabia, it is called the permanent Committee for Islamic research and fatāwō, established in 1971, whose central core is to issue fatāwo $\bar{a} .{ }^{59}$ Muslim countries that do not institutionalize siyāsa shar'iyya or have no clause stipulating 'shari $a$ as a/the source of law' in their Constitution are deemed to have replaced the old structure of shari' $a$ authority with new legal institutions. Muslims trust the new legal institution more than the old structures of shari 'a authority in law and governance. Officeholders mostly make critical legal decisions of the state instead of the ulama. ${ }^{60}$ Scrutiny of the legislative and regulatory process in particular Islamic countries may reveal different conclusions, especially on how the ulama's opinions (fatāwo $\bar{a}$ and admonition) are taken into account in formulating public policy by the government.

The most significant of these councils are MUI, Persis, Nahdlatul Ulama, and Muhammadiyah. Nahdlatul Ulama was established in 1926 and started issuing fatāwa as early as its first congress in 1926 through the process called bahthu-l-masā'il. Muhammadiyah was established in 1912 and began issuing fatāw $\bar{a}$ in 1927 following the institution of a select committee assigned to deal with religious issues in general, and Islamic law in particular, called majlis tarjih. ${ }^{61}$ These two organizations are often said to be the largest Muslim organizations in the world. However, as discussed earlier, MUI has become the most authoritative Muslim institution in producing a fatwa in Indonesia over the last ten years. Fatāwā or tausiyya have been sought from MUI by individuals as well as both government and non-governmental agencies so as not to be contradictory to shari ' $a .{ }^{62}$ Hence, there has

${ }^{59}$ See Nadirsyah Hosen, "Hilal and Halal: How to Manage Islamic Pluralism in Indonesia?," Asian Journal of Comparative Law 7, no. 1 (2012): 4.

60 See, e.g., Jan Michiel Otto, ed., Sharī' a Incorporated: A Comparative Overview of the Legal System of Twelve Muslim Countries in Past and Present (Leiden: Leiden University Press, 2010), 19-20, 33, 617, 629.

61 Deliar Noer, Modernist Muslim Movement in Indonesia 1900-1942 (Singapore: Oxford University Press, 1973), 8, 80-82, 231-232.

${ }^{62}$ Adams, Pola Penyerapan, 174, 180. 
been a return of Islamic legal authority to epistemic authority in the administration of Islamic legal tradition in Indonesia. This authority is held by MUI because of the absence of an official fatwa institution in Indonesia and a combination of de facto and de jure recognition of the epistemic authority of the fatwa institution owned by MUI, namely FC-MUI.

\section{Conclusion}

Following the regulatory changes since Soeharto's fall in 1998, MUI's formal role in the state system for the administration of Islamic legal traditions in Indonesia has expanded, especially into the field of shari ' $a$ economy. These changes have intensified MUI's influence and the legal authority of its fatāwā. MUI continues to expand its authority in fatwa production in Indonesia by making the Fatwa Commission of MUI the single institution for fatwa production in Indonesia. In doing so, MUI has engaged with as many fatwa $\bar{a}$ commissions and Islamic organizations as possible in the fatwo production by organizing the biannual-collective ijithād forum called Ijtima Ulama, where contemporary problems faced by Indonesian Muslims are sought to be resolved.

Theoretically, the Ijtima Ulama's resolutions have more valid fatwa because it involves almost all ulama in Indonesia. In exercising and maintaining its status as the most authoritative institution in fatwa production, the Fatwa Commission of MUI thus acts as the Ijtima Ulama resolutions reviewer before promulgating them fatwa $\bar{a}$. Some Ijtima Ulama resolutions which do not pass the review, therefore, cannot/are not promulgated as a fatwa. MUI adopts this measure in order to increase the efficacy of its fatāw $\bar{a}$ because it provides legal determinacy in the matter sought for answer by perfecting the collective ijtihād resolutions of all fatwā bodies in Indonesia.

\section{References}

Adams, Wahiduddin. Pola Penyerapan Fatwa Majelis Ulama Indonesia (MUI) dalam Peraturan Perundang-Undangan 19751997. Jakarta: Bagian Proyek Peningkatan Informasi Penelitian dan Diklat Keagamaan, 2004. 
Alfitri. "Protecting Women from Domestic Violence: Islam, Family Law, and the State in Indonesia." Studia Islamika 27, no. 2 (2020): 273-307.

Alfitri. "Religion and Constitutional Practices in Indonesia: How Far Should the State Intervene in the Administration of Islam?" Asian Journal of Comparative Law 13, no. 2 (December 2018): 389-413.

Alfitri. "Whose Authority? Contesting and Negotiating the Idea of a Legitimate Interpretation of Islamic Law in Indonesia." Asian Journal of Comparative Law 10, no. 2 (December 2015): 191-212.

Alfitri. "Whose Authority? Interpreting, Imposing, and Complying with Corporate Zakat Obligations in Indonesia." PhD Thesis, University of Washington, 2015.

Gillespie, Piers. "Current Issues in Indonesian Islam: Analysing the 2005 Council of Indonesian Ulama Fatwa No. 7 Opposing Pluralism, Liberalism and Secularism." Journal of Islamic Studies 18, no. 2 (May 2007): 202-240.

Hallaq, Wael B. A History of Islamic Legal Theories: An Introduction to Sunni Usul al-Fiqh. Cambridge: Cambridge University Press, 1997.

- - - . Authority, Continuity and Change in Islamic Law. Cambridge: Cambridge University Press, 2001.

- - - "Juristic Authority vs. State Power: The Legal Crises of Modern Islam." Journal of Law and Religion 19, no. 2 (2003): 243-258.

Hasyim, Syafiq. "Fatwas and Democracy: Majelis Ulama Indonesia (MUI, Indonesian Ulema Council) and Rising Conservatism in Indonesian Islam." TRaNS: Trans-Regional and -National Studies of Southeast Asia 8, no. 1 (May 2020): 21-35.

- - . "Majelis Ulama Indonesia and Pluralism in Indonesia." Philosophy \& Social Criticism 41, no. 4-5 (May 2015): 487-495.

- - - "The Council of Indonesian Ulama (Majelis Ulama Indonesia, MUI) and Religious Freedom." Irasec's Discussion Papers 12 (2011): 3-26.

Hooker, M. B. "Islam and Medical Science: Evidence from Malaysian and Indonesian Fatāwā, 1960-1995." Studia Islamika 4, no. 4 (1997). Accessed January 5, 2021. http://journal.uinjkt. ac.id/index.php/studia-islamika/article/view/764. 
Hosen, Nadirsyah. "Behind the Scenes: Fatwas of Majelis Ulama Indonesia (1975-1998)." Journal of Islamic Studies 15, no. 2 (May 2004): 147-179.

- - - "Fatwa and Politics in Indonesia." In Sharia and Politics in Modern Indonesia, edited by Arskal Salim and Azyumardi Azra, 168-180. Singapore: ISEAS, 2003.

- - - "Hilal and Halal: How to Manage Islamic Pluralism in Indonesia?" Asian Journal of Comparative Law 7, no. 1 (2012): 118.

- - - "Nahdlatul Ulama and Collective Ijtihad." New Zealand Journal of Asian Studies 6, no. 1 (2004): 5-26.

Ichwan, Moch. Nur. "'Ulamā', State and Politics: Majelis Ulama Indonesia after Suharto." Islamic Law and Society 12, no. 1 (2005): 45-72.

Lindsey, Tim. Islam, Law and the State in Southeast Asia. Vol. 1: Indonesia. London: I.B. Tauris, 2012.

- - - "Monopolising Islam: The Indonesian Ulama Council and State Regulation of the 'Islamic Economy.'” Bulletin of Indonesian Economic Studies 48, no. 2 (2012): 253-274.

- - - "Monopolising Islam: The Indonesian Ulama Council and the State Regulation of 'the Islamic Economy.'" Bulletin of Indonesian Islamic Studies 48, no. 2 (2012): 253-274.

Lombardi, Clark B., and R. Michael Feener. "Why Study Islamic Legal Professionals?" Pacific Rim Law E Policy Journal 21, no. 1 (January 2012): 1-12.

Majelis Ulama Indonesia. 15 Tahun Majelis Ulama Indonesia: Wadah Musyawarah para Ulama, Zu`ama dan Cendekiawan Muslim. Jakarta: Sekretariat MUI, n.d.

- - - Compilation of Decisions: National Working Meeting of MUI in 2011, 2011.

- - - Himpunan Fatwa MUI Sejak 1975. Jakarta: Erlangga, 2011.

Mudzhar, Muhammad Atho. Fatwas of the Council of Indonesian Ulama: A Study of Islamic Legal Thought in Indonesia 1975-1988. Jakarta: INIS, 1993.

Nafis, M. Cholil. Teori Hukum Ekonomi Syariah: Kajian Komprehensif tentang Teori Hukum Ekonomi Islam, Penerapannya dalam Fatwa Dewan Syariah Nasional dan Penerapannya ke dalam Peraturan Perundang-undangan. Jakarta: Universitas Indonesia, 2011. 
Nasir, Mohamad Abdun, and Asnawi. "The Majelis Ulama's Fatwā on Abortion in Contemporary Indonesia." The Muslim World 101, no. 1 (2011): 33-52.

Noer, Deliar. Modernist Muslim Movement in Indonesia 1900-1942. Singapore: Oxford University Press, 1973.

Olle, John. "The Majelis Ulama Indonesia versus 'Heresy': The Resurgence of Authoritarian Islam." In State of Authority: The State in Society in Indonesia, edited by Gerry van Klinken and Joshua Barker, 95-116. Ithaca: Cornell Southeast Asia Program, 2009.

Otto, Jan Michiel, ed. Sharì a Incorporated: A Comparative Overview of the Legal System of Twelve Muslim Countries in Past and Present. Leiden: Leiden University Press, 2010.

Sirry, Mun'im. "Fatwas and Their Controversy: The Case of the Council of Indonesian Ulama (MUI)." Journal of Southeast Asian Studies 44, no. 1 (February 2013): 100-117.

"Pedoman dan Prosedur Penetapan Fatwa Majelis Ulama Indonesia, chapter II 'Basic and Character of Fatwa', Chapter III 'Methods to Promulgate Fatwa,'” n.d. 